\title{
Institutions and Resource-driven Development
}

\author{
LÁSZLÓ SZALAI
}

Received: 28.02.2018; Revised: 02.05.2018; Accepted: 15.05.2018

\begin{abstract}
According to the resource curse hypothesis abundant resources are likely to impede economic growth and social development. However, empirical evidences are controversial as numerous studies found that the direct effects of abundance are either insignificant, non-monotonic, or positive, while the negative indirect effects arise when natural wealth crowds-out other fundamental sources of growth. Further research on the different development outcomes concluded that the growth effects are also conditional on the quality of both public and private institutions. Political economy explanations argue that abundance leads to patronage and myopic rent-seeking behaviour under weak institutions, whereas it fosters economic growth if the institutional environment of the extraction promotes sound revenue management, transparency, and accountability. This paper aims to synthetize the findings on the interaction between institutions and natural resources and gives an overview of the policy proposals on mitigating the negative indirect effects.
\end{abstract}

JEL codes: O43, Q32, Q38

Keywords: Resource curse, Institutional quality, Political economy, Economic growth

\section{Introduction}

Despite the intense academic debate there is still no consensus on the role of natural resources in terms of economic growth and social progress (Papyrakis, 2017). Classic theories suggest that resource abundance has positive development effects as windfalls from extraction boost real living standards by supporting higher levels of consumption, investment, and public spending. The subsequent demand expansion gives the necessary big-push to the economy and helps to escape the low-income equilibrium trap (Sachs \& Warner, 1999). Spill-overs from primary extraction generate incentives for the investors to incur the relatively high costs of industrialisation while government revenues create an opportunity to finance core public goods such as education, healthcare, or physical infrastructure. The extended size of the internal markets enables infant industries to achieve the economies of scale and diverts the economy to an improved development path. As resource revenues "saw the seeds" of economic growth, the secondary positive effects are expected to be significant even after the depletion of the natural wealth.

However, a remarkable body of empirical studies from the past two decades reported contradictory findings. Sachs and Warner (1995) presented the first statistical evidence of the resource curse as a result of a cross-country regression analysis on the sources of economic development. They showed that countries with a higher initial share of resource-

a Budapest University of Technology and Economics, Budapest, Hungary. e-mail: szalai@kgt.bme.hu 
based exports tended to experience slower growth between 1970 and 1990. The same paper also suggests that higher investment rates, more effective legal institutions, and open trade policies have positive growth effects (Sachs \& Warner, 1997). Further research verified their results on the level of the broad concept and subsequently the resource curse hypothesis have attracted significant academic interest (Davis, 2013). Although numerous studies reported supporting evidence (Gylfason, 2001b; James \& Aadland, 2011; Satti et al., 2014), others have rejected the hypothesis and argued that the growth effects of abundance are either insignificant or positive (Alexeev \& Conrad, 2011; Smith, 2015). According to a recent survey, $40 \%$ of the empirical studies found negative effects, $40 \%$ found no effects, and $20 \%$ found positive effects (Havranek et al., 2016). This paper aims to address these contradictory results and intends to provide a coherent explanation for the different development outcomes. Early theoretical understanding of the adverse growth effects was based on the Dutch disease

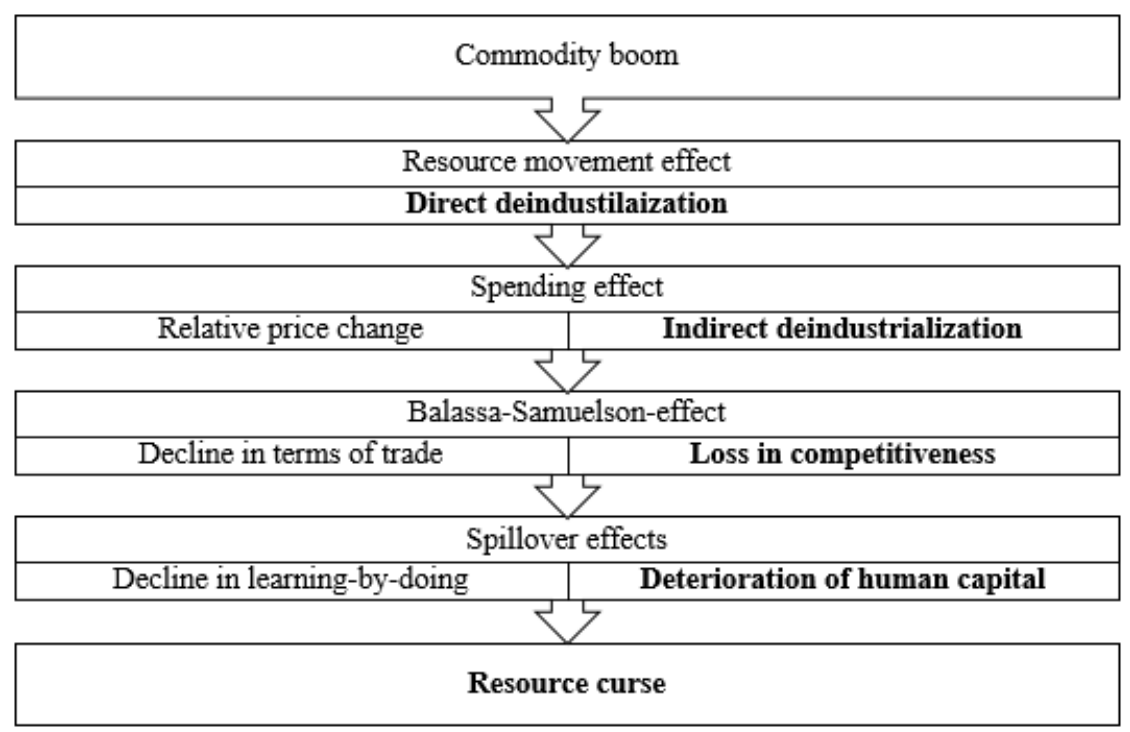

Figure 1: The Dutch disease

Source: Author's compilation

model (Corden \& Neary, 1982; van Wijnbergen, 1984; Yokoyama, 1989). In 1959, a large reserve of hydrocarbons was discovered under the Dutch shelf of the North Sea but its extraction only began after the rise in the commodity prices due to the 1973 oil crisis. In the following years the Netherlands experienced surprisingly slow economic growth and a considerable setback in manufacturing. These negative outcomes were associated with the deindustrialising effects of a commodity boom in a small open economy. Consider a threesector economy producing natural resources and manufactured goods as tradables, while the output in the service sector is non-tradable. The prices of the tradables are exogenous, whereas the prices of the services are flexible according to the domestic demand and supply. Also assume that the sectors are utilizing a single specific input while labour always moves towards to equalize its returns in all sectors, thus the value of the marginal product necessary equals to the real wage. 
Following the commodity boom, the marginal product increases in resource extraction and workers start to flow from the other sectors in the hope of a higher real wage. This resource movement effect cuts the quantity of labour employed in manufacturing and causes direct deindustrialisation. On the other hand, higher real wages drive the demand for domestic services and boost their prices. The value of the marginal product increases in the service sector and the subsequent rise in the real wage causes more workers to quit manufacturing. Thus, this spending effect induces indirect deindustrialisation. Moreover, both effects trigger an increase in the relative prices of non-tradables which in turn causes the real appreciation of the domestic currency. As a consequence of the Balassa-Samuelson effect, the international terms of trade decline and the manufacturing sector loses from its competitiveness. In this framework, the resource curse evolves as the further downfall in production leaves the country vulnerable to the volatility of the international commodity prices. The booming resource extraction crowds-out manufacturing as well as the positive spillover effects associated with the production of manufactured goods. On the long run, the decline in learning-by-doing causes the human capital to deteriorate and pushes the country into a development-trap.

Although the Dutch disease theory succeeded to explain the macroeconomic growth failures, it has nothing to say about the prosperous resource-economies. Resource abundant countries have different development experiences and many of them performed well in terms of economic growth. However, the negative effects in the Dutch disease model are unconditional and monotonic; the more abundant the country is the worse is the outcome is. This conclusion obviously contradicts the empirical data as resource-economies like Norway, Australia, or Botswana are regularly listed among the top economic performers. Further research revealed that the resource curse is a more diverse phenomenon which has widespread effects on economic, social, and political development.

Explaining the different growth experiences in a coherent theoretical framework has turned out to be a hard case. Controversial empirical evidence suggests that the presence of the resource curse has to be conditional on country-specific factors. The identification of these factors and the description of their transmission channels became the focal point of academic interest. Significant studies emphasize the distinction between resource abundance (stocks) and resource dependence (flows) to resolve the empirical controversies. Dependence is usually measured by the export share of unprocessed commodities or by the ratio of resource rents compared to the domestic product, whereas abundance is calculated on the basis of per capita subsoil assets. In such terms, the Sachs and Warner (1995) analysis and the Dutch disease theory associate the negative growth effects with resource dependence but not with abundance. This paper aims to address the conditional mechanisms which turn abundance into dependence and clog economic and social development.

Section 2 and 3 discuss both the economic and the political aspects of the resource curse and outline the most recognized theories as shown on Figure 2. Section 4 describes the role of institutions and shows how their quality determines the development outcome. Section 5 is dedicated to the interactions between resources and institutions, while Section 6 discusses the conclusions and summarizes the policy proposals on the mitigation of the negative growth effects. 


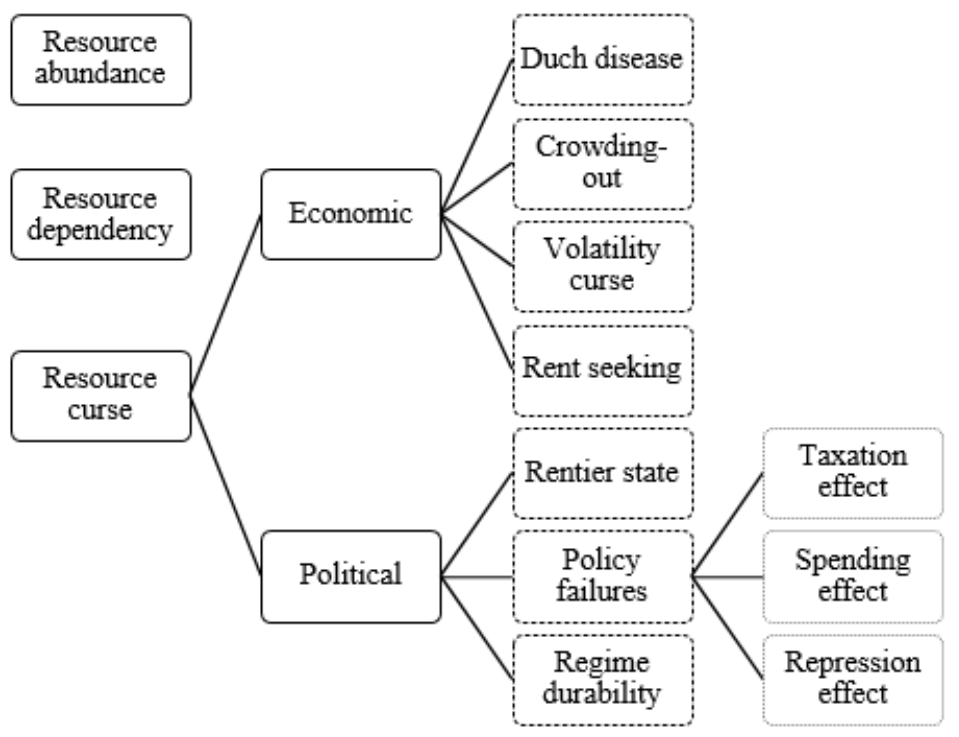

Figure 2: Different explanations of the resource curse

Source: Author's compilation

\section{The economic resource curse}

Since natural wealth is a component of the productive capital resource abundant countries are expected to have better development prospects. Numerous studies claim that the direct effects of resource abundance are positive and the resource curse evolves through intermediate transmission channels. Economic growth failures are the consequences of indirect mechanisms as natural wealth crowds-out other fundamental sources of growth. The crowding-out affects the accumulation of all other capital components and diverts economic actors from productive activities to rent-seeking. In this context, the resource curse emerges when the adverse indirect effects offset the direct positive effects as it shown on Figure 3.

Gylfason (2006) identified five intermediate channels of crowding-out in terms of the components of productive capital. The first one follows directly from the Dutch disease theory as the real appreciation of the domestic currency causes the external terms of trade to decline. The subsequent loss of international competitiveness distracts the investors from manufacturing and cuts inward FDI-flows. Furthermore, the comparative advantage in the resource sector induces export specialization in low-tech extraction and impedes technology diffusion (Lee, 2011). Thus, natural wealth crowds-out the most productive elements of foreign capital. The second channel concerns the distribution of resource rents. Carmignani (2013) showed that rents from the extraction sector tend to increase inequality, and higher inequality lowers the average level of human development. In this sense, resource extraction crowds-out social capital as it creates internal tensions and undermines social cohesion and trust. The third transmission mechanism arises from the relative high level of nonwage incomes in resource-driven economies. Windfalls provide a false sense of security and lower the excess returns on skilled labour which generate less incentive to invest in education. Significant theoretical and empirical evidences support that secondary enrolment rates and educational expenses are generally lower in resource-rich countries (Cockx \& Francken, 
2016; Gylfason, 2001a; Shao \& Yang, 2014; Wadho, 2014). Moreover, the crowding-out of human capital is more pronounced in the absence of the positive feedback from learningby-doing. The fourth channel concerns resource allocation, savings, and the effectiveness of investments. Most abundant countries tend to have low or negative genuine saving rate (van der Ploeg, 2010), that is, they consume their natural capital faster than they accumulate other capital components. While domestic savings are insufficient for sustainable growth, a further problem involves not just the quantity but also the quality of investments. Resource-deficiency puts a premium on allocative efficiency whereas abundance favours for white elephant projects with negative social value. Robinson and Torvik (2005) showed that windfalls generate political incentives to misallocate resources from productive investments to symbolic projects. Put differently, natural wealth crowds-out savings, investments, and physical capital as well (Gylfason \& Zoega, 2006). The fifth channel suggests that resource windfalls crowd-out financial capital by deteriorating financial markets and intermediaries. Crowding-out explanations are consistent with the classic theories as they argue that the

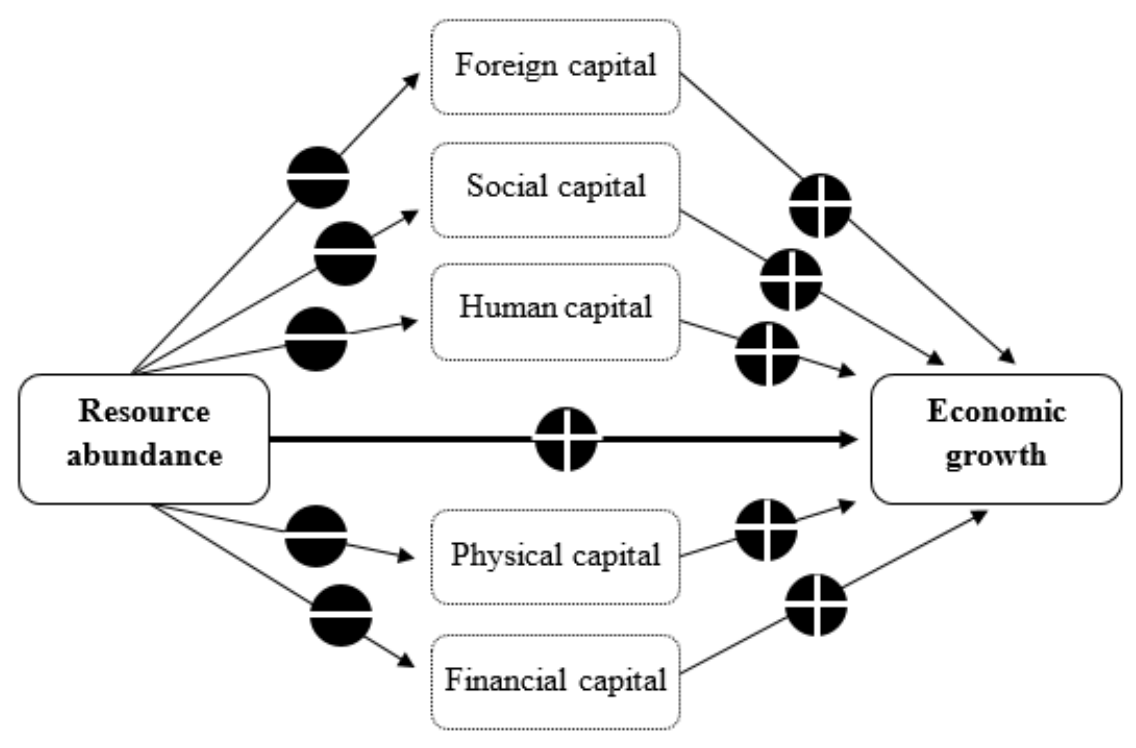

Figure 3: Indirect transmission channels

Source: Author's compilation

direct growth effects of abundance are positive and the resource curse only evolves if the indirect negative effects outweigh them. Papyrakis and Gerlagh (2004) estimated the relative importance of each indirect channel based on their contribution to the curse. According to them the most decisive mechanism is the crowding-out of investments as it cancels out $41 \%$ percent of the direct positive effects on growth. They argue that natural resources are expected to provide a continuous stream of future revenues which is less dependent on the accumulation of physical capital. Therefore, economic actors have less incentive to make savings and investments which in turn exposes the country to the volatility risk of international commodity prices (van der Ploeg \& Poelhekke, 2009). The second and the third channels concern the effects of natural resources on the degree of openness and on the external terms of trade. On one hand, the crowding-out of manufacturing pushes policy 
makers to impose tariffs, quotas, or other trade barriers to favour for domestic producers. But protectionism puts a burden on trade openness and impedes long term growth as it was suggested by Sachs \& Warner. On the other hand, the real appreciation of the currency and the decline in the terms of trade cause a loss in competitiveness and further deindustrialisation. Each channel contributes $21 \%$ to the negative indirect effects and resemble the consequences of the Dutch disease theory. Together referred as the international channel, they draw up the most significant indirect mechanism. The fourth channel with $11 \%$ share is the educational or schooling channel which corresponds with the crowding-out of human capital as described earlier. The least important mechanism counts for $6 \%$ of the aggregate effects and concerns the level of corruption. Although the positive relation between resource abundance and corruption is robust, the effects of corruption on economic growth seem relatively small if compared to the other indirect channels.

The crowding-out of capital components on the macro level is a consequence of the distortion of microeconomic incentives generated by resource windfalls. Excess rents drive economic actors to allocate more of their effort, talent, and time to extraction and less to production. That is, resource abundance crowds-out productive activities on the micro level. On one hand rents tend to increase income, but on the other hand they generate a displacement effect as more and more actors engage in rent-seeking. These adverse effects are more pronounced if there are increasing returns to scale in manufacturing or if rentseeking activities induce negative external effects. When a producer shifts to grabbing, the profitability of all other producers decreases due to the loss in positive demand externalities. The opportunity cost of rent-seeking declines which in turn generates further incentives to switch from production to grabbing (Kolstad \& Wiig, 2009b). Therefore, the displacement effect is self-reinforcing and the resource curse evolves as it outweighs the direct positive effect of abundance.

\section{The political resource curse}

Besides the adverse effects on economic growth, there is strong evidence that abundant countries tend to perform worse in terms of social and political development as well. The political resource curse hypothesis suggests that abundance increases the level of corruption, the durability of authoritarian regimes, and the risk of violent conflicts (Ross, 2015). Moreover, political economy explanations argue that macroeconomic growth failures are essentially policy failures and the resource curse is a political outcome. According to Auty (2001), abundant countries are likely to evolve to a rentier or predatory political state which distorts the economy in the pursuit of rents. Politicians tend to over-extract natural resources relative to the efficient path as they discount the future with the probability of being re-elected (Robinson et al., 2014). In this context, the development-trap is a consequence of resource misallocation and macroeconomic policy failures. Ross (2001) identifies three main transmission mechanisms of the rentier effect.

The first one concerns how abundance affects tax policies and political accountability. Resource rents provide an independent flow of income and decrease the government's need to raise revenue by taxation. However, low taxes reduce the public interest in sound revenue management as well as the demand for democratic accountability (McGuirk, 2013). Taxation is also considered to be an important step in state formulation as a part of the social contract between a state and its citizens (Colgan, 2014). Resource rents are likely to 
deteriorate this contract and fuel corruption. Therefore, the taxation effect also contributes to the crowding-out of the social capital. Crivelli and Gupta (2014) reported a significant negative relationship between resource revenues and total domestic revenues, including for the major tax components. They argue that a weak tax regime exposes the budget to the volatility of international commodity prices and leads to pro-cyclical fiscal policy. Thus, the adverse growth effects are political outcomes as policy failures divert the economy below its potential development path.

The second component is called the spending effect and it concerns the allocative efficiency of the resource revenues. Windfalls provide an opportunity to the government to raise political support by income redistribution and to implement populist public policies (Mazzuca, 2013). The control over the rents appreciates the economic value of political power which drives the elite to engage in patronage and increase public spending. Clientelism crowds-out productive activities as the government offers ineffective public employment in exchange for loyalty. Many studies found supporting evidence of the incumbency advantage (Wantchekon, 2002), that is, resource revenues tend to increase regime durability and political survival in authoritarian regimes (Smith, 2004; Wright et al., 2015). Another intense debate concerns the relation between resource abundance and democracy. While an influential analysis by Haber and Menaldo (2011) found no evidence of negative effects on the long run, more recent research seems to disprove their results and claims that natural wealth tends to block democratic transitions (Andersen \& Ross, 2014; Wiens et al., 2014).

The third component is referred as the repression effect. In a rentier state, economic competition is political competition and excess grants create a strong incentive for the political elite to repress the opposition. At the same time resource rents provide enough funds for the government to prevent the formation of state-independent social groups and monopolize the political power. The increased durability of the abundant authoritarian regimes is due to their ability to protect themselves against the seizures of power by other competitors. A related empirical result is that resource abundance was shown to increase the risks of domestic civil strife (Collier \& Hoeffler, 1998) and external (Colgan, 2014) armed conflicts.

\section{The institutional condition}

Although the aforementioned theories of the resource curse succeeded to explain the growth failures, they failed to address a variety of resource-driven development outcomes. While oil wealth seems like a curse to Venezuela, Norway executed sound revenue management policies and became a top performer in terms of various development indicators (Holden, 2013). Having diamonds caused conflicts and growth failures in case of Sierra Leone or Liberia but catalysed rapid development in Botswana. The significantly different growth experiences suggest that the resource curse has to be conditional and non-monotonic. The largest segment of the literature claims that the growth effects are determined by the interaction between the natural resources and the institutional environment of the extraction (Gilberthorpe \& Papyrakis, 2015).

Resource abundance seems to be a blessing in case of good institutions and assumed to turn into a curse if the institutional quality is poor. Boschini et al. (2007) emphasize what they call the appropriability of a resource as a determinant of the interaction between certain types of resources and the quality of institutions in terms of the growth effects. Appropri- 
ability has two dimensions; technical appropriability describes the physical and economical characteristics of the resource while institutional appropriability evaluates the environment of the extraction. Point-source natural resources are technically more appropriable if they are easier to extract, store, or transport, need fewer processing, and trading them involves less transaction costs. Put differently, diamonds or crude oil are more appropriable than arable land as they provide better opportunities to extract rents. According to the appropriability hypotheses the growth effect of abundance improves with institutional quality and this relation is the more pronounced if the resources are technically more appropriable. On one hand, natural resources have different potential to trigger the curse, while on the other this potential appears to be conditioned by the institutional quality. Thus, abundance only turns to dependence if coupled with poor institutions and this institutional reversal is found to be robust in various empirical specifications (Boschini et al., 2013).

Political economy theories of the resource curse provide various explanations of how institutional quality determines the development effects. An influential work by Acemoglu et al. (2001) suggest that institutional quality is the most decisive factor on the historical perspective. They showed that the mortality rate of the European colonizers correlates negatively with economic growth in the colonized countries. According to them, colonizers set up extractive institutions in places they could not permanently settle but replicated the European framework where the conditions were suitable. Extractive institutions did not introduce much protection for the property rights or for the rule of law but their only purpose was to support the exploitation of the natural wealth. These colonial institutions persisted even after the independence and induced the resource curse in many African countries, whereas the European model promoted growth in colonies like Australia, Canada, or the United States.

The rentier effect and the crowding-out of production also seem to be conditional on the quality of institutions. Mehlum et al. (2006) presented a microeconomic model where entrepreneurs have to choose between productive activities and rent-seeking (grabbing). The equilibrium allocation depends on the relative profitability of the activities which is assumed to be influenced by the institutional quality. Under producer-friendly (good) institutions all entrepreneurs are producers whereas poor institutions give rise to a grabber-equilibrium. Production and rent-seeking are complementary activities under good institutions but compete under poor institutions. That is, resource abundance boosts production and economic growth if institutions are producer-friendly but sets on the curse if they are grabber-friendly. Mehlum et al. (2006) also present supporting empirical evidences in the form of a crosscountry regression analysis on per capita growth. The proxy for the institutional quality was an average of five indexes concerning the rule of law, the level of corruption, the bureaucratic quality, the risk of expropriation, and the reputation of contracts. Their results show a positive correlation between growth and an interaction term of resource intensity and institutional quality which suggests that resources are rather a blessing then a curse if institutions are good enough. Further research on the conditional development effects concluded that the results are robust against various indicators of institutional quality (Szalai, 2011).

Robinson et al. (2006) proposed a model of clientelism which suggests that the spending component of the rentier effect is also conditional on the institutions. The model features two periods with an incumbent politician wishing to be re-elected. Besides other results they conclude that resource booms raise the value of being in power and provide excess 
income for the incumbent to influence the outcome of the elections. The model captures patronage as an offer of employment in the inefficient public sector which opens a channel to redistribute resource windfalls. The equilibrium outcome depends on the ability of the incumbent to influence the elections by public employment. Under political institutions that favour for transparency and accountability, the potential to influence the outcome is low and the incumbent chooses to raise support by promoting effective resource allocation. However, poor institutions give rise to a clientelist equilibrium where resources are misallocated in order to finance public employment in exchange of political support. In correspondence with the model, a significant body of the literature emphasizes the role of transparency and accountability in resource revenue management. Most papers confirmed that the resource curse is conditional on the quality of political institutions (Bhattacharyya \& Hodler, 2010; Corrigan, 2014; Williams, 2011).

The various resource-driven growth experiences suggest that the curse is not just conditional but the adverse effects are also non-monotonic. Mehrara (2008) revealed a threshold effect in terms of resource intensity, that is natural resources only hinder economic growth if rents contribute a significant share of the domestic product. In case of 13 oil-exporting countries he found that the negative effects only appear when the sum of the rents exceeds a share of $18 \%$ and claims that the growth effects are positive below the threshold (Mehrara, 2009). He suggests that heavily oil-dependent countries lack the institutional mechanism to de-link fiscal expenditures from current resource revenues which in turn leads to myopic and pro-cyclical macroeconomic policy. Sarmidi et al. (2014) identified another threshold effect in terms of institutional quality. Using the dataset by Brunnschweiler and Bulte (2008) they found a non-linear relation between resource-driven growth and the quality of institutions. Countries below the structural break feature poor institutional quality and prone to the curse, whereas countries above the threshold derive positive growth effects from resource abundance. Their data show that 64 out of 90 countries in the sample have the sufficient level of institutional quality to escape the curse.

The condition on the resource curse seems to be a robust result with strong empirical verification in different institutional dimensions. Keenan (2014) emphasizes the role of international institutions in revenue management as they are less prone to local rent-seeking and have a potential to positively influence the domestic environment. Kolstad (2009) examined which institutions matter the most; rent-seeking models of the resource curse concern institutions governing the private sector whereas patronage models associate with institutions governing the public sector. Although he concluded that only private institutions play a significant role in conditioning the curse, a more recent study found supporting evidence for political institutions as well (Bhattacharyya \& Hodler, 2014).

\section{Endogenous institutions}

The desire to possess and exploit natural resources was a significant factor throughout the modern history. According to Drelichman (2005) the enormous wealth of the New World drove the Spanish conquistadors to fight the indigenous civilizations and transport large quantities of precious metals back to Europe. However, the feudalistic Spanish Empire experienced a long-term stagnation in the following seventeenth century and failed to adopt early capitalism. The curse evolved as windfalls drove the unproductive nobility into rent-seeking and distracted resources from industrialisation. As another example, Etkind 
(2011) argues that Siberian fur trade created a caste-like local society where the population was dependent on a narrow elite of violent hunters. Russia's modern dependency on oil stems from these social norms as they were structurally prone to clientelism. Institutional quality conditions the resource curse, but abundance also seems to shape the development of institutions.

Wiens (2014) distinguishes between two broad type of domestic institutions. Restrictive institutions empower a broad coalition of citizens to effectively check policy formation and implementation, while unrestrictive institutions fail to limit the sovereign's discretion over resource revenues and policy decisions. Both the economic and the political resource curse is associated with unrestrictive institutions as they drive the sovereign to allocate windfalls in ways that inhibit sustainable economic productivity and undermine executive accountability. However, Wiens suggests that the persistence of unrestrictive institutions is endogenous in terms of natural wealth and argues that the institutional outcome is a result of a political bargain between the sovereign and the citizens. The bargaining leverage is determined by two parameters; the extent of the sovereign's dependence on citizens to retain political power and the credibility of supporters' exit threats. Resource revenues make the sovereign less dependent due to the taxation effect and undermine the credibility of exit threats through the spending and repression effects. Thus, resource abundance favors for the persistence of poor quality institutions. Wiens concludes to the endogenous institutions thesis and claims that the resource curse is only avoidable if restrictive institutions are implemented before the country becomes fiscally reliant on resource revenues. Unrestrictive institutions release the sovereign from the need for negotiation and undermine the incentives for a positive institutional change. In other words, poor institutions cause the resource curse which in turn clogs the institutional development and pushes the country into a development trap.

Besides the results on increased regime durability, resource abundance also tends to hinder democratic transitions and conserves clientelist structures. In contract-intensive economies individual actors obtain their income from the marketplace whereas under clientelistic institutions they engage in rent-seeking. In accordance with the story of the Syberian fur trade, Aytaç et al. (2016) argue that a clientelistic economy is a prerequisite for the resource curse and countires with conract-intensive institutions are immune from it. Their results suggest that abundant clientelist regimes distribute resource rents in exchange for political support which undermines the effort for democratization. This feedback makes the resource curse persistant as endogenousity inhibits the development of contract-intensive institutions. Further studies also reported supporting evidence for the negative effect of resource intensity on a broad set of instutional indicators (Blanco et al., 2015).

Kolstad and Wiig (2009b) interpret institutional quality as an equilibrium outcome which arise as a result of repeated interactions between agents. A gradual change is difficult because the underlying dynamics tends to pull back the institutions to the bad equilibrium. The resource curse turns to a stubborn problem as excess rents give a negative feedback in case of poor institutions. Institutional quality is the determinant as well as the consequence of the resource curse which suggest that the initial conditions are likely to be conserved. Abundance is a blessing if coupled with good institutions but it evolves to an everlasting curse if the extraction precedes the institutional reforms. 


\section{Concluding remarks}

Explaining the very different growth experiences of resource-driven economies within a framework of a coherent theory turned out to be a hard case. Empirical data suggest that the adverse effects of abundance are indirect, conditional, and non-monotonic. Natural wealth crowds-out productive activities and other components of capital only if poor quality institutions provide opportunities for rent-seeking. The negative effects are more pronounced if the productive sector features positive demand externalities and technology diffusion. Poor institutions cause macroeconomic policy failures and the mismanagement of the windfalls as resource dependence gives rise to a rentier political state. Moreover, institutional development itself seems to be endogenous in terms of natural wealth. Abundance is a blessing if a country had already implemented good institutional quality before experiencing a resource boom, but turns into dependency in case of poor institutions. The resource curse is likely to be persistent due to its negative feedback on the quality of institutions.

The conditional resource curse hypothesis suggests that policy proposals should focus on enhancing the quality of institutions. Most scholars advocate the significance of transparency and accountability in the process of resource revenue management and redistribution (Mejía Acosta, 2013). A strong public control over the windfalls improves efficiency, reduces the possibility of clientelism or corruption, (Kolstad \& Wiig, 2009a) and promotes economic diversification (Ville \& Wicken, 2013). Others urge to focus on the fundamentals of social development such as equal access to land, primary education, or healthcare. However, endogenous institutions seem to be resistant against domestic attempts of incremental changes which turns the curse into a stubborn problem. 


\section{References}

Acemoglu, D., Johnson, S., \& Robinson, J. A. (2001). The Colonial Origins of Comparative Development: An Empirical Investigation. American Economic Review, 91 (5), 13691401. doi:10.1257/aer.91.5.1369

Alexeev, M., \& Conrad, R. (2011). The natural resource curse and economic transition. Economic Systems, 35(4), 445-461. doi:10.1016/j.ecosys.2011.04.

Andersen, J. J., \& Ross, M. L. (2014). The Big Oil Change: A Closer Look at the Haber-Menaldo Analysis. Comparative Political Studies, 47(7), 993-1021. doi:10.1177/0010414013488557

Auty, R. M. (2001). The political economy of resource-driven growth. European Economic Review, 45(4-6), 839-846. doi:10.1016/S0014-2921(01)00126-X

Aytaç, S. E., Mousseau, M., \& Ömer Faruk Örsün. (2016). Why some countries are immune from the resource curse: The role of economic norms. Democratization, 23(1), 71-92. doi:10.1080/13510347.2014.964216

Bhattacharyya, S., \& Hodler, R. (2010). Natural Resources, Democracy and Corruption. European Economic Review, 54(4), 608-621. doi:10.1016/j.euroecorev.2009.10.004

Bhattacharyya, S., \& Hodler, R. (2014). Do Natural Resource Revenues Hinder Financial Development? The Role of Political Institutions. World Development, 57, 101-113. doi:10.1016/j.worlddev.2013.1

Blanco, L. R., Nugent, J. B., \& O'Connor, K. J. (2015). Oil Curse and Institutional Changes: Which Institutions are Most Vulnerable to the Curse and Under What Circumstances? Contemporary Economic Policy, 33(2), 229-249. doi:10.1111/coep.12077

Boschini, A., Pettersson, J., \& Roine, J. (2013). The Resource Curse and its Potential Reversal. World Development, 43, 19-41. doi:10.1016/j.worlddev.2012.1

Boschini, A. D., Pettersson, J., \& Roine, J. (2007). Resource Curse or Not: A Question of Appropriability. The Scandinavian Journal of Economics, 109(3), 593-617. doi:10.1111/j.1467-9442.2007.00509.x

Brunnschweiler, C. N., \& Bulte, E. H. (2008). The Resource Curse Revisited and Revised: A Tale of Paradoxes and Red Herrings. Journal of environmental economics and management, 55(3), 248-264. doi:10.1016/j.jeem.2007.08.004

Carmignani, F. (2013). Development Outcomes, Resource Abundance, and the Transmission Through Inequality. Resource and Energy Economics, 35(3), 412-428. doi:10.1016/j.reseneeco.2013.

Cockx, L., \& Francken, N. (2016). Natural Resources: A Curse on Education Spending? Energy Policy, 92, 394-408. doi:10.1016/j.enpol.2015.12.0

Colgan, J. D. (2014). Oil, Domestic Politics, and International Conflict. Energy Research E3 Social Science, 1, 198-205. doi:10.1016/j.erss.2014.03.005

Collier, P., \& Hoeffler, A. (1998). On Economic Causes of Civil War. Oxford Economic Papers, 50(4), 563-573. doi:10.1093/oep/50.4.563

Corden, W. M., \& Neary, J. P. (1982). Booming Sector and De-Industrialisation in a Small Open Economy. The Economic Journal, 92(368), 825-848. doi:10.2307/2232670

Corrigan, C. C. (2014). Breaking the Resource Curse: Transparency in the Natural Resource Sector and the Extractive Industries Transparency Initiative. Resources Policy, 40(1), 
17-30. doi:10.1016/j.resourpol.2014.

Crivelli, E., \& Gupta, S. (2014). Resource Blessing, Revenue Curse? Domestic Revenue Effort in Resource-rich Countries. European Journal of Political Economy, 35, 88-101. doi:10.1016/j.ejpoleco.2014.0

Davis, G. A. (2013). Replicating Sachs and Warner's Working Papers on the Resource Curse. The Journal of Development Studies, 49(12), 1615-1630. doi:10.1080/00220388.2013.807501

Drelichman, M. (2005). All That Glitters: Precious Metals, Rent Seeking and the Decline of Spain. European Review of Economic History, 9(3), 313-336. doi:10.1017/S1361491605001528

Etkind, A. (2011). Barrels of Fur: Natural Resources and the State in the Long History of Russia. Journal of Eurasian Studies, 2(2), 164 - 171. doi:10.1016/j.euras.2011.03.007

Gilberthorpe, E., \& Papyrakis, E. (2015). The Extractive Industries and Development: The Resource Curse at the Micro, Meso and Macro Levels. The Extractive Industries and Society, 2(2), 381 - 390. doi:10.1016/j.exis.2015.02.008

Gylfason, T. (2001a). Natural Resources, Education, and Economic Development. European Economic Review, 45(4), 847 - 859. doi:10.1016/S0014-2921(01)00127-1

Gylfason, T. (2001b). Nature, Power and Growth. Scottish Journal of Political Economy, 48(5), 558-588. doi:10.1111/1467-9485.00215

Gylfason, T. (2006). Natural Resources and Economic Growth: From Dependence to Diversification. In H. G. Broadman, T. Paas, \& . P. J. J. Welfens (Eds.), Economic Liberalization and Integration Policy (pp. 201-231). Heidelberg: Springer-Verlag. doi:10.1007/3-540-31183-1_10

Gylfason, T., \& Zoega, G. (2006). Natural resources and economic growth: The role of investment. The World Economy, 29(8), 1091-1115. doi:10.1111/j.14679701.2006.00807.x

Haber, S., \& Menaldo, V. (2011). Do Natural Resources Fuel Authoritarianism? A Reappraisal of the Resource Curse. American Political Science Review, 105(1), 1-26. doi:10.1017/S0003055410000584

Havranek, T., Horvath, R., \& Zeynalov, A. (2016). Natural Resources and Economic Growth: A Meta-Analysis. World Development, 88, 134-151. doi:10.1016/j.worlddev.2016.0

Holden, S. (2013). Avoiding the Resource Curse the Case Norway. Energy Policy, 63, 870-876. doi:10.1016/j.enpol.2013.09.010

James, A., \& Aadland, D. (2011). The Curse of Natural Resources: An Empirical Investigation of US Counties. Resource and Energy Economics, 33(2), 440-453. doi:10.1016/j.reseneeco.2010.05.006

Keenan, P. J. (2014). International Institutions and the Resource Curse. Penn State Journal of Law \& International Affairs, 3(1), 216-260.

Kolstad, I. (2009). The Resource Curse: Which Institutions Matter? Applied Economics Letters, 16(4), 439-442. doi:10.1080/17446540802167339

Kolstad, I., \& Wiig, A. (2009a). Is Transparency the Key to Reducing Corruption in Resource-rich Countries? World development, 37(3), 521-532. doi:10.1016/j.worlddev.2008.07.002

Kolstad, I., \& Wiig, A. (2009b). It's the Rents, Stupid! The Political Economy of the Resource Curse. Energy Policy, 37(12), 5317-5325. doi:10.1016/j.enpol.2009.07.055 
Lee, J. (2011). Export Specialization and Economic Growth Around the World. Economic Systems, 35(1), 45-63. doi:10.1016/j.ecosys.2010.11.002

Mazzuca, S. L. (2013). The Rise of Rentier Populism. Journal of Democracy, 24(2), 108-122. doi:10.1353/jod.2013.0034

McGuirk, E. F. (2013). The Illusory Leader: Natural Resources, Taxation and Accountability. Public Choice, 154(3-4), 285-313. doi:10.1007/s11127-011-9820-0

Mehlum, H., Moene, K., \& Torvik, R. (2006). Institutions and the Resource Curse. The economic journal, 116(508), 1-20. doi:10.1111/j.1468-0297.2006.01045.x

Mehrara, M. (2008). The Asymmetric Relationship between Oil Revenues and Economic Activities: The Case of Oil-exporting Countries. Energy Policy, 36(3), 1164-1168. doi:10.1016/j.enpol.2007.11.004

Mehrara, M. (2009). Reconsidering the Resource Curse in Oil-exporting Countries. Energy Policy, 37(3), 1165-1169. doi:10.1016/j.enpol.2008.10.040

Mejía Acosta, A. (2013). The Impact and Effectiveness of Accountability and Transparency Initiatives: The Governance of Natural Resources. Development Policy Review, 31 (s1). doi:10.1111/dpr.12021

Papyrakis, E. (2017). The Resource Curse - What have We Learned from Two Decades of Intensive Research: Introduction to the Special Issue. The Journal of Development Studies, 53(2), 175-185. doi:10.1080/00220388.2016.1160070

Papyrakis, E., \& Gerlagh, R. (2004). The Resource Curse Hypothesis and Its Transmission Channels. Journal of Comparative Economics, 32(1), 181-193. doi:10.1016/j.jce.2003.11.002

Robinson, J. A., \& Torvik, R. (2005). White Elephants. Journal of Public Economics, 89(2-3), 197-210. doi:10.1016/j.jpubeco.2004.05.004

Robinson, J. A., Torvik, R., \& Verdier, T. (2006). Political Foundations of the Resource Curse. Journal of development Economics, 79(2), 447-468. doi:10.1016/j.jdeveco.2006.01.008

Robinson, J. A., Torvik, R., \& Verdier, T. (2014). Political Foundations of the Resource Curse: A Simplification and a Comment. Journal of Development Economics, 106, 194-198. doi:10.1016/j.jdeveco.2013.09.004

Ross, M. L. (2001). Does Oil Hinder Democracy? World politics, 53(3), 325-361. doi:10.1353/wp.2001.0011

Ross, M. L. (2015). What Have We Learned about the Resource Curse? Annual Review of Political Science, 18, 239-259. doi:10.1146/annurev-polisci-052213-040359

Sachs, J. D., \& Warner, A. M. (1995). Natural Resource Abundance and Economic Growth (National Bureau of Economic Research Working Papers No. 5398). doi: $10.3386 /$ w5 5398

Sachs, J. D., \& Warner, A. M. (1997). Natural Resource Abundance and Economic Growth [Mimeo, Harvard University Cambridge].

Sachs, J. D., \& Warner, A. M. (1999). The Big Push, Natural Resource Booms and Ggrowth. Journal of Development Economics, 59(1), 43-76. doi:10.1016/S0304-3878(99)00005$\mathrm{X}$

Sarmidi, T., Hook Law, S., \& Jafari, Y. (2014). Resource Curse: New Evidence on the Role of Institutions. International Economic Journal, 28(1), 191-206. doi:10.1080/10168737.2013.787110 
Satti, S. L., Farooq, A., Loganathan, N., \& Shahbaz, M. (2014). Empirical Evidence on the Resource Curse Hypothesis in Oil Abundant Economy. Economic Modelling, 42, 421-429. doi:10.1016/j.econmod.2014.07.020

Shao, S., \& Yang, L. (2014). Natural Resource Dependence, Human Capital Accumulation, and Economic Growth: A Combined Explanation for the Resource Curse and the Resource Blessing. Energy Policy, 74, 632-642. doi:10.1016/j.enpol.2014.07.007

Smith, B. (2004). Oil Wealth and Regime Survival in the Developing World, 19601999. American Journal of Political Science, 48(2), 232-246. doi:10.1111/j.00925853.2004.00067.x

Smith, B. (2015). The Resource Curse Exorcised: Evidence from a Panel of Countries. Journal of Development Economics, 116, 57-73. doi:10.1016/j.jdeveco.2015.04.001

Szalai, L. (2011). Paradox of Plenty. In . H.-D. W. L. Balogh D. Meyer (Ed.), Analysis of Monetary Institutions and Space (pp. 111-138). Kaposvár: BERG-Verlag.

van der Ploeg, F. (2010). Why Do Many Resource-rich Countries Have Negative Genuine Saving?: Anticipation of Better Times or Rapacious Rent Seeking. Resource and Energy Economics, 32(1), 28-44. doi:10.1016/j.reseneeco.2009.07.002

van der Ploeg, F., \& Poelhekke, S. (2009). Volatility and the Natural Resource Curse. Oxford economic papers, 61(4), 727-760. doi:10.1093/oep/gpp027

van Wijnbergen, S. (1984). The 'Dutch Disease': A Disease After All? The Economic Journal, 94(373), 41-55.

Ville, S., \& Wicken, O. (2013). The Dynamics of Resource-based Economic Development: Evidence from Australia and Norway. Industrial and Corporate Change, 22(5), 13411371. doi:10.1093/icc/dts040

Wadho, W. A. (2014). Education, Rent Seeking and the Curse of Natural Resources. Economics \&3 Politics, 26(1), 128-156. doi:10.1111/ecpo.12029

Wantchekon, L. (2002). Why Do Resource Dependent Countries Have Authoritarian Governments? Journal of African Finance and Economic Development, 2(1), 57-77.

Wiens, D. (2014). Natural Resources and Institutional Development. Journal of Theoretical Politics, 26(2), 197-221. doi:10.1177/0951629813493835

Wiens, D., Poast, P., \& Clark, W. R. (2014). The Political Resource Curse: An Empirical Re-evaluation. Political Research Quarterly, 67(4), 783-794. doi:10.1177/1065912914543836

Williams, A. (2011). Shining a Light on the Resource Curse: An Empirical Analysis of the Relationship between Natural Resources, Transparency, and Economic Growth. World Development, 39(4), 490-505. doi:10.1016/j.worlddev.2010.08.015

Wright, J., Frantz, E., \& Geddes, B. (2015). Oil and Autocratic Regime Survival. British Journal of Political Science, 45(2), 287-306. doi:10.1017/S0007123413000252

Yokoyama, H. (1989). Export-led Industrialization and the Dutch Disease. The Developing Economies, 27(4), 427-445. doi:10.1111/j.1746-1049.1989.tb00171.x 